\title{
THE ANALYSIS OF SOCIAL ENTREPRENEURIAL INTENTION AMONG YOUNG GENERATION (STUDY CASE: STUDENT OF FACULTY OF BUSINESS PRESIDENT UNIVERSITY)
}

\author{
HangkaPanca Buana ${ }^{1}$ \\ Yunita Ismail Masjud ${ }^{2}$ \\ ${ }^{1}$ President University, hangkabuana@gmail.com \\ 2President University, yunitaismail@president.ac.id
}

\begin{abstract}
This research conducted to measure the factors that influence social entrepreneurial intention of young generation with use President University Faculty of Business students. It has three independent variables (empathy, self efficacy and exposure) and one dependent variable (social entrepreneurial intention). Quantitative research chosen as an approach and using questionnaire as a collection data instrument.The questionnaire distributed through online (google form, social media) to 557 respondents and the response received were 334 (59.96\% response rate). Multiple regression used to analyze the data gathered. All 20 items in the questionnaire have passed the validity and reliability test by using pearsoncorrelation and cronbachalpha. Then multiple regression analysis shown that all independent variables were significance influence to dependent variable. From three independent variables, the self efficacy as the highest influence towards social entrepreneurial intention (39.7\%), followed by exposure $(34.4 \%)$ and empathy $(25.3 \%)$. The regression model was: $\quad Y=1.073+0.253 X 1+0.397 \mathrm{X} 2+0.344 \mathrm{X} 3+\mathrm{e}$. From t-test and F-test, showed that all the independent variables (empathy, self efficacy and exposure) had significant effect towards the dependent variable (social entrepreneurial intention) and it also had simultaneously significant effect towards social entrepreneurial intention. Lastly, this research explained $40.4 \%$ variation of social entrepreneurial intention could explain by empathy, self efficacy and exposure, while the rest (59.6\%) explained by other factors that was not included in this research.
\end{abstract}

Keywords: Empathy, self efficacy, exposure, social entrepreneurial intention

\section{ABSTRAK}

Penelitian ini dilakukan untuk mengukur faktor-faktor yang mempengaruhi niat kewirausahaan sosial generasi muda dengan menggunakan mahasiswa President University Fakultas Bisnis. Ini memiliki tiga variabel independen (empati, self efficacy dan paparan) dan satu variabel dependen (niat wirausaha sosial). Penelitian kuantitatif dipilih sebagai pendekatan dan menggunakan kuesioner sebagai instrumen pengumpulan data. Kuisioner didistribusikan melalui online (formulir google, media sosial) kepada 557 responden dan respons yang diterima adalah 334 (tingkat respons 59,96\%). Regresi berganda digunakan untuk menganalisis data yang dikumpulkan. Semua 20 item dalam kuesioner telah lulus uji validitas dan reliabilitas dengan menggunakan korelasi pearson 
dan cronbachalpha. Kemudian analisis regresi berganda menunjukkan bahwa semua variabel independen berpengaruh signifikan terhadap variabel dependen. Dari tiga variabel independen, efikasi diri sebagai pengaruh tertinggi terhadap intensi kewirausahaan sosial $(39,7 \%)$, diikuti oleh paparan $(34,4 \%)$ dan empati $(25,3 \%)$. Model regresi adalah: $\mathrm{Y}=1,073+0,253 \mathrm{X} 1+0,397 \mathrm{X} 2+0,344 \mathrm{X} 3+$ e. Dari uji-t dan uji-F, menunjukkan bahwa semua variabel independen (empati, self efficacy dan paparan) memiliki pengaruh signifikan terhadap variabel dependen (niat wirausaha sosial) dan juga secara simultan berpengaruh signifikan terhadap niat wirausaha sosial. Terakhir, penelitian ini menjelaskan $40,4 \%$ variasi niat kewirausahaan sosial dapat dijelaskan dengan empati, self efficacy, dan paparan, sedangkan sisanya $(59,6 \%)$ dijelaskan oleh faktor-faktor lain yang tidak termasuk dalam penelitian ini.

Kata kunci: Empati, self efficacy, paparan, intensi kewirausahaan sosial

\section{A. Introduction}

Entrepreneurship is an establishment of a business in order to give impact to a nation's wealth, job creation and also standard of living for better economy of a country (Marire et al., 2017). The large number of entrepreneurs compared to the population will give positive impact to the socio-economic condition in a country. This importance makes the entrepreneurship become the view that entrepreneurship become the major drivers for socio-economic progress and expansion since it will create more jobs opportunities and impacts to a nation's wealth (Marire et al., 2017). All countries in the world needs more entrepreneurs for better economy condition, including Indonesia. Indonesia as one of the big countries by population which ranked in the 4th position in the world (Worldometers, 2018) needs more entrepreneurs to make sure that the job opportunity for the population are enough. In fact number of entrepreneurs in Indonesia is still low compared to the neighboring countries (Kominfo, 2017). Indonesia has only $3.1 \%$ entrepreneurs of 260 million or around 7.8 million people. Although it has increased from previous year, but it is still lower than other countries Malaysia $5 \%$, China $10 \%$, Singapore $7 \%$, Japan $11 \%$ and the US $12 \%$ (Depkop.go.id, 2017; Setnas ASEAN Indonesia, 2018). On the other hand, the existence of entrepreneurs will increase the job creation within a country which means that it will create more job fields (Moses et al., 2016). As the result of lack of entrepreneurs, the unemployment in Indonesia exists. The data below exhibit the unemployment condition in Indonesia which derived from (Badan Pusat Statistik, 2018). 
Table 1: Open Unemployment Rate

\begin{tabular}{|c|c|c|c|}
\hline $\begin{array}{c}\text { Employment Condition } \\
\text { Status }\end{array}$ & August 2017 & February 2018 & $\begin{array}{c}\text { August } \\
2018\end{array}$ \\
\hline Open Unemployment Rate & $5.50 \%$ & $5.13 \%$ & $5.34 \%$ \\
\hline
\end{tabular}

Source : Badan Pusat Statistik, (2018)

The data indicates that the reduction of unemployment in Indonesia is still fluctuate, therefore, Indonesia need acatalyst to improve the condition and the existence of entrepreneurs could be the answer. The existence of unemployment will cause more problems. It may cause physical and mental health, family dynamics and loss of income (Nichols, Mitchell, \& Lindner, 2013).

Then, Human Development Index of Indonesia in 116 of 189 countries $(61.37 \%$ of the member countries). The rank indicates that Indonesoa is still in not really good position or classified as medium human development. The number of unemployment in Indonesia also affected by the quality of manpower in Indonesia in terms of qualifications and competenc. The fluctuate number of unemployment will lead to social problems such as poverty and Indonesia needs real solution to press the social problems which caused by the limited job opportunities (Sofia, 2015). This condition aggravated by the fact that Indonesia is in ASEAN Economic Community that indicates the competitiveness of labor is increasing (Sofia, 2015). One of the way to deal with the issue is through social entrepreneurship since it covers both sides, social and economy since the social mission becomes the business orientation. As the first stage of a desired behaviour, the factors that influence entreprenurial intention need to be more explored as the purpose to increase the number of entrepreneurs in Indonesia. Entrepreneurial intention defined as the commitment to start a venture (Tran \& Korflesch, 2017). It is the mental orientation like desire to create an enterprise in the future. Entrepreneurial intention refers to the dynamics of individual ability in identifying the opportunities in order to create new value (Luc, 2018)

Therefore, in the context of social entrepreneur, social entrepreneurial intention is the desire and commitment of someone to create a social enterprise in the future. The exploration of intention is needed since it is the first stage of a desired behavior (Hockerts, 2017).

The millenials tends to have less empathy nowadays (Enright, 2019), it indicates that the millenials are not really care to other people and after they graduate, they will tend to be profit oriented. This condition is contradictive to social entrepreneurs view and how come they can set up social venture in the future while their empathy are less. Then, talking about self efficacy that can be defined as the capability to execute certain actions. It shows about their confidence about their ability regarding certain actions. The millenials are the generations that are not really like to be risk-taker (Lee, 2016). Then, the millenials do not really have interest in entrepreneurship (Brandon, 2018). This condition indicates that the millenials are not really sure about their self efficacy in terms of entrepreneurship. Then, as the 
terms of social entrepreneurship is still a new concept (Kenya Connection, 2016), the millenials may have less informations regarding this issue, so they may have less interest in this issue. In addition, this research conducted for the purpose of increasing the number of social entrepreneurs in Indonesia in the future since the number of social entrepreneurs are still low (988 entities) compared to common entrepreneurs. (PLUS, 2018)(Ashoka Foundation, 2018)

This research conducted in Faculty of Business in President University, and the entrepreneurship course is taught but not for social entrepreneurship, meanwhile it may affect the orientation of the students to set up the commercial enterprise without considering about the social entrepreneurship. This research aims to answer the problems are:

1. Does empathy has significant effect to social entrepreneurial intention of students in President University Faculty of Business?

2. Does self efficacyhas significant effect to social entrepreneurial intention of students in President University Faculty of Business?

3. Does exposure has significant effect to social entrepreneurial intention of students in President University Faculty of Business?

4. Do empathy, self efficacy and exposure has significant effect to social entrepreneurial intention of students in President University Faculty of Business?

\section{B. Literature Review}

\section{Social Entrepreneurship}

The term of social entrepreneurship introduced in around 1970 as the response towards social problems. Its emergence keep moving forward in around 1980 with the establishment of Ashoka Foundation that give supports to the social entrepreneurs around the world (Ebrashi, 2013; Kusumasari, 2015). Social Entrepreneurship (SE) means that it is not only give something, but it teach something to be more sustainable in long-term period (Sutha \& Sankar, 2016) . According to Tran \& Korflesch, 2017 social entrepreneurs will create innovative solutions for the immediate problems that will lead to sustainable social transformations. Social Entrepreneur is part of the entrepreneur that also concern to the social problems while it runs the business. It will use business principle even capitalism to create social change (Tran \& Korflesch, 2017)

However, the important thing that differs SE with other forms of entrepreneurship is the "hybrid" forms which is not only concern to business activities, but it adds social value and gives innovative solutions to the problems (Tran \& Korflesch, 2017). It becomes the central point and remarkable distinction of the entrepreneurship forms compared to other forms of entrepreneurships. Social entrepreneurship also a profit-seeking businesses, but it has purpose to achieve social value (Chipeta, 2015). Social entrepreneurship means that social entrepreneurship is the combination of high passion in social mission with 
discipline, innovation, persistence as the business world does. The activities of social entrepreneurship includes : a.) not profit oriented; b.) doing business for social purpose, and c.) the combination of both of them which is not for seeking for profit, but for social purpose (Utomo, 2015). The previous statement is in accordance with Schwab Foundation, 2018 which defines social entrepreneurship as the solution to solve social problems towards entrepreneurial approach. This concept also strengthen by other social entrepreneurship researchers which defines social entrepreneurship as "hybrid" form which pursues 2 bottom lines, which are concentrating on profit and the other on social values (Rostiani et al., 2014).

\section{Social Entrepreneurial Intention}

Intention of individuals can help to indicate the reason why the individual want to start a venture before they search for opportunities (Urban, 2015; Wang et al., 2016). The concept of entrepreneurial intention means that the selfacknowledgement of an individuals who has conviction to set up a venture at some point in the future (Urban, 2015). Exploring this concept as the purpose to promote the entrepreneurship got high attention from the researchers. Their inferences occupy important place for the policy makers in the purpose of entrepreneurship promotion especially for the developing economy countries which are less stable (Haqueet al., 2017). In the context of social entrepreneurship, the intention can be defined as the self-acknowledgement of an individual to set up social venture in the future. It is very important since the social entrepreneurs will give economic and social value to the society.

\section{Empathy}

Empathy is how a human can feel the emotion of others. It started from a person evaluate the conditions whether he or she is angry, sad,embarrassed, etc. (Wondra \& Ellsworth, 2015). The empathy lead to the outcomes such as caring for others, understanding others, validating the emotions of others(Jamil, 2014). The term empathy will take the perspective of others regarding the emotions. The person who has empathy will feel the same condition to the others that they observed and lead to the behavior of caring to others(Jamil, 2014). Taking the perspective of others is a part of empathy when it leads to the action of caring to others.

Hypothesis 1: There is influence of empathy toward social entrepreneurial intention.

\section{Self-Efficacy}

Self-efficacy is the concept that refers to the social cognitive theory by Albert Bandura (Bandura, 1986; Urban, 2015). It has meaning about the personal judgement of their capabilities to execute courses and action to attain certain performances (Bandura, 1986). Self-efficacy focuses measurement of performance capabilities rather than personal qualities. In the most entrepreneurship research, self-efficacy becomes the proxy of entrepreneurial intention (Izquierdo, 2013). A 
survey that conducted among the students in Cambridge University and University Ljubljana reveals that the self-efficacy is the most influential factors compared to other predictors in entrepreneurial intention research (Esfandiar et al., 2017). The higher entrepreneurial self-efficacy associated by the higher conviction in preparing the new enterprise which includes the high confidence in doing the entrepreneurial tasks (Ip et al., 2017). The condition indicates that this concept becomes has a big attention in entrepreneurship research. In the context of social entrepreneurship, self-efficacy means the personal belief of an individual to contribute towards the social problems (Ip et al., 2017). Previous research also found that self-efficacy becomes an important antecedent of pro-social behavior such as blood donations (Hockerts, 2017). In addition, the potential social entrepreneurs in emerging market indicates the high level of self-efficacy, since it will be related with high level of innovativeness which lead to social impact and sustainability (Ip et al., 2017; Urban, 2015).

Hypothesis 2: There is influence of self-efficacy toward social entrepreneurial intention

\section{Exposure}

Exposure means how closely the individual exposed to the entrepreneurial activities. As the result, the individual accustomed to see entrepreneurial activities and moreover get inspired. Exposure provides an individual not only to familiarity, but an experienced networks who give advice, insight, and encouragement towards entrepreneurial activities(Amanamah et al., 2018). The access to entrepreneurial networks has positive influence to entrepreneurial intention in order to overcome fear, lack of experience and various business activities challenges (Amanamah et al., 2018). In social entrepreneurship, exposure to social issues also past experience will lead to the social entrepreneurial intention (Chipeta, 2015)

Hypothesis3: There is influence of exposure towards social entrepreneurial intention

Hypothesis 4: There is influence of the combination of empathy, self-efficacy, and exposure toward social entrepreneurial intention 


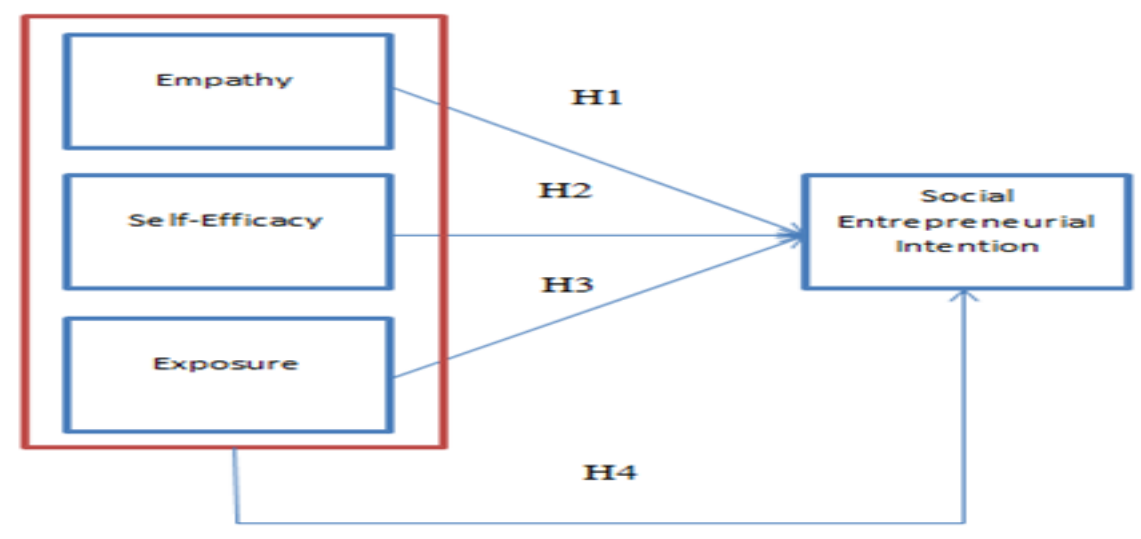

Figure 1. Theoretical Framework

Source: Hockerts, 2017; Wilton \& Venter, 2016

\section{Research Method}

The questionnaire response received (Google Form) from Faculty of Business Major (Management, Accounting, and Business Administration) in President university from December 2018 until early January 2019.Then, 17 respondents were not met the criteria and 334 were met the criteria, so the 334 responses were analyzed in data analysis. The questionnaire consists of 20 items which measures all variables (empathy, eelf efficacy, exposure and social entrepreneurial intention). The items in the questionnaire were adopted from (Wilton \& Venter, 2016) and using five-point Likert Scale (1=Strongly Disagree; 2=Disagree; 3=neutral; 4=Agree; $5=$ Strongly Agree). To make sure that the respondents were the targeted respondents, the questionnaire consists of screening questions such as "Are you a business student?" and " Have you ever learned entrepreneurship (subject, courses, etc.)" . The researcher using experience of entrepreneurial subject as the criteria, since it will lead to entrepreneurial intention (Moses et al., 2016; Sutha \& Sankar, 2016). Lastly, multiple regression was used to analyze the independent variables towards dependent variable and also using software as the tools for data anlysis. 


\section{Results and Discussion}

\section{a. Demographic of the Sample}

Respondent demographic condition showing by Figure 2.

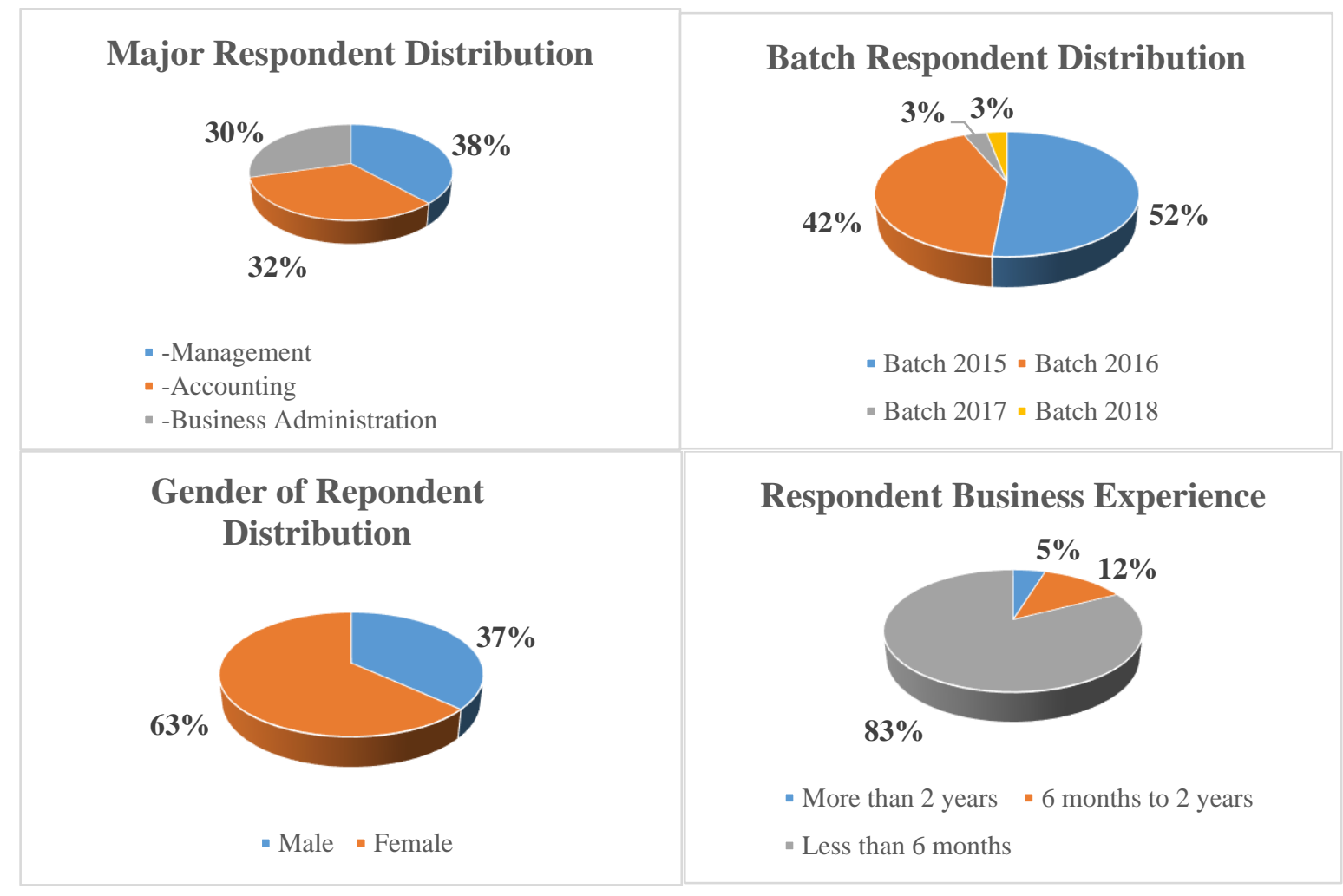

Figure 2. Respondent Profile

From Figure2., respondent distributed among three major (30\% from BA, 38\% from Management and $32 \%$ from Accounting). Base on batch, $51 \%$ respondent from batch 2015, 42\% from batch 2016 and 3\% from 2017 and 3\% from 2018. This batch distribution because respondent chosen purposively, and female respondent (63\%) more than male (37\%). Almost all respondent (83\%) had less than 6 months business experience, especially when they took Business Project.

\section{b. Multiple Regression}

In this research, model used multiple regression. Calculation of this model using software and the result showing on Table 2. 
Table 2: Multiple Regression Calculation

\begin{tabular}{|c|c|c|c|c|c|c|c|c|}
\hline \multicolumn{9}{|c|}{ Coefficients $^{a}$} \\
\hline \multirow[b]{2}{*}{ Model } & & \multicolumn{2}{|c|}{ Unstandardized Coefficients } & \multirow{2}{*}{$\begin{array}{c}\text { Standardized } \\
\text { Coefficients } \\
\text { Beta }\end{array}$} & \multirow[b]{2}{*}{$\mathrm{t}$} & \multirow[b]{2}{*}{ Sig. } & \multicolumn{2}{|c|}{ Collinearity Statistics } \\
\hline & & $\mathrm{B}$ & Std. Error & & & & Tolerance & VIF \\
\hline \multirow[t]{4}{*}{1} & (Constant) & 1,073 & 1,408 & & .762 & .447 & & \\
\hline & Total_EM &, 253 & .079 & .155 & 3,218 & ,001 &, 772 & 1,295 \\
\hline & Total_SEF & 397 & .070 & ,288 & 5,685 &, 000 & ,699 & 1,430 \\
\hline & Total_EX & 344 & .045 & 365 & 7,660 & .000 & .790 & 1,266 \\
\hline
\end{tabular}

a. Dependent Variable: Total_SEI

Source: Calculation primary data

The result indicated that all the independent variables, had significant influence to dependent variable, but the constant did not significance. Then the multiple regression equation will be:

\section{$Y=1.073+0.253$ Empathy +0.397 Self Efficacy +0.344 Exposure $+e$}

Constant did not significance, it was mean, social entrepreneurial intention not occurred if that three variable did not occurred. For each independent variable indicated that every $1 \%$ increased in empathy would increased social entrepreneurial intention as much $25.3 \%$; every $1 \%$ increased in self-efficacy would increase social entrepreneurial intention as much $39.7 \%$; every $1 \%$ increased in exposure would increase social entrepreneurial intention as much $34.4 \%$.

For the model, proceed doing the classical assumption in order to ensured the credibility of the regression model. For normality test, it has bell-shaped histogram which means that it passed the test (Figure 3). For multicollinearity test, it had also passed the test since the VIF value and Tolerance for all variables met the criteria (Tolerance $>0.1$ and VIF $<10$ ) (See Table 2). Lastly, heterocedasticity test could be seen from scatterplot and it passed the test since there was no specific pattern there (Figure 4).

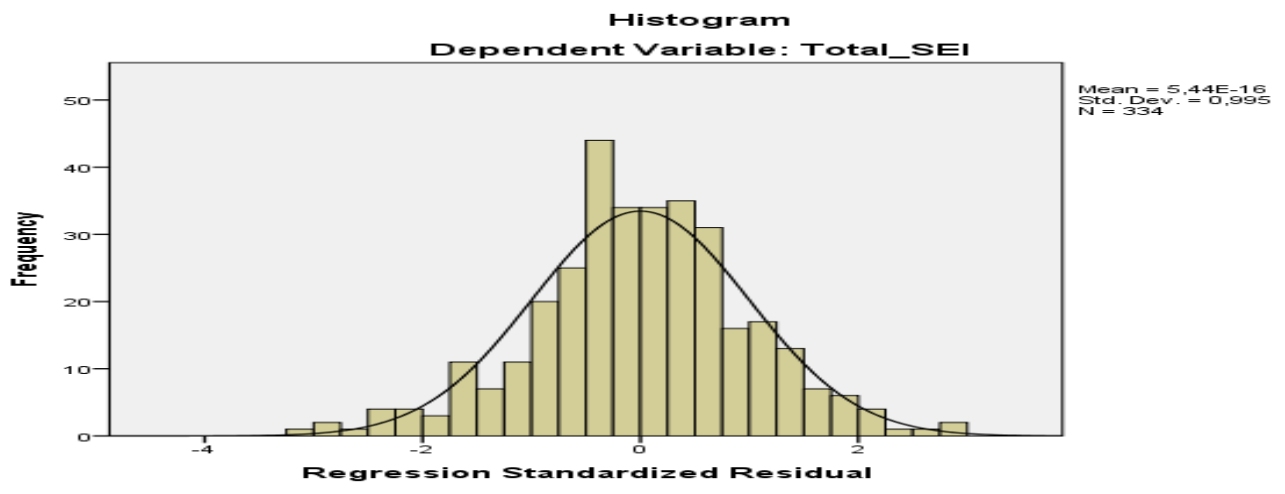

Figure 3 : Histogram with the bell-shape for Normality Test 


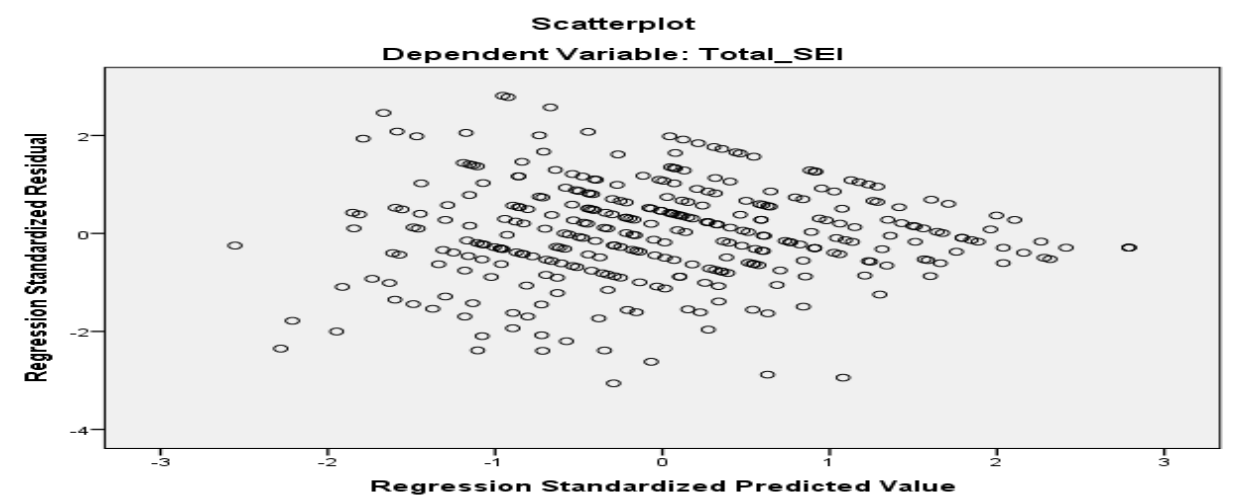

Figure 4: Scatterplot for Heteroscedasticity Test

\section{c. Hypothesis Testing}

By looking at the Table 2, the result shown that hypothesis 1, hypothesis 2 and hypothesis 3 were accepted, since the sig. value were less than $\alpha=0.05$. It means that empathy, self efficacy and exposure had influence towards social entrepreneurial intention. Hypothesis4 also accepted since the F-Test table shown that the sig. value was less than $\alpha=0.05$

\section{Table 3: F-Test Result}

\begin{tabular}{|c|c|c|c|c|c|c|}
\hline \multicolumn{7}{|c|}{ ANOVA $^{a}$} \\
\hline Model & & $\begin{array}{l}\text { Sum of } \\
\text { Squares }\end{array}$ & df & Mean Square & $\mathrm{F}$ & Sig. \\
\hline \multirow[t]{3}{*}{1} & Regression & 2330,223 & 3 & 776,741 & 76,094 &, $000^{b}$ \\
\hline & Residual & 3368,510 & 330 & 10,208 & & \\
\hline & Total & 5698,734 & 333 & & & \\
\hline
\end{tabular}

\section{Source: Calculation primary data}

For model, calculation of coefficient determination got 0.404 . It is mean, empathy, self efficacy and exposureexplained as much $40.4 \%$ as a factors that influence social entrepreneurial intention and for rest which is $59.6 \%$ were influenced by other factors. R square value show in Table 4. 
Table 4. $\mathrm{R}$ square Calculation

\begin{tabular}{|c|c|c|c|c|c|}
\hline \multicolumn{6}{|c|}{ Model Summary } \\
\hline Model & $\mathrm{R}$ & R Square & $\begin{array}{l}\text { Adjusted R } \\
\text { Square }\end{array}$ & $\begin{array}{l}\text { Std. Error of } \\
\text { the Estimate }\end{array}$ & $\begin{array}{l}\text { Durbin- } \\
\text { Watson }\end{array}$ \\
\hline 1 & $639^{a}$ & 409 &, 404 & 3,195 & 1,968 \\
\hline \multicolumn{6}{|c|}{ a. Predictors: (Constant), Total_EX, Total_EM, Total_SEF } \\
\hline
\end{tabular}

\section{Source: Calculation primary data}

From multiple regression model showed that self-efficacy had the biggest contribution to social entrepreneurial intention (regression coefficient is 0.397 ). According to Izquierdo, 2013, self-efficacy becomes the proxy of entrepreneurial intention. Social entrepreneurial intention, like entrepreneurial intention, need to get full support from the entrepreneur. Based on survey among Cambridge University students and University Ljubljana students, conclude that self-efficacy is the most influential factors compared to other predictors in entrepreneurial intention research (Esfandiar, et all., 2017). The same result with research of Hockerts, 2017 that found self-efficacy becomes an important antecedent of pro-social behavior such as blood donations. The potential social entrepreneurs in emerging market indicates the high level of self-efficacy, since it will be related with high level of innovativeness which lead to social impact and sustainability (Ip et al., 2017; Urban, 2015).Then, self-efficacy, become a prominent factor in entrepreneurial intention research and this research also had the sam e result. Self efficacy refers to the capability in executing certain course of action. The result shown that the students who feel that he/she had enough capability in handling situation and also enough leadership will influence social entrepreneurial intention.

The next influence factor on social entrepreneurial intention is exposure. Entrepreneurial activity inspired the individual exposed to doing that. The access to entrepreneurial networks has positive influence to entrepreneurial intention in order to overcome fear, lack of experience and various business activities challenges (Amanamah et all., 2018). Exposure to social issues also pat experience will lead to the social entrepreneurial intention (Chipeta, 2015). Exposure had also influece towards social entrepreneurial intention. If the students have enough exposure regarding social entrepreneurship (family, education, direct experiece), it will lead to social entrepreneurial intention. Then, the millenials should get more exposure regarding social entrepreneurship. It may be in the form of insight, experience of the role models, networks etc, so that they may have intention to set up social enterprise in the future.

The last factor is empathy, with 0.253 point increased social entrepreneurial intention. The empathy lead to the outcomes such as caring for others, understanding others, validating the emotions of others (Jamil, 2014). The people 
with empathy will had social feeling that feel the same condition to the others. Empathy will lead to social entrepreneurial intention since the students with empathy will feel what others feel by caring others, understanding others, validating emotion of others. But, the students tend to have less empathy and they prefer to be more profit oriented after they graduated rather than thinking about other people. Therefore, the implementation of social entrepreneurship course should increase the level of empathy of the students.

The three factor are together influenced on social entrepreneurial intention, which proved by $\mathrm{F}$ test. Social entrepreneurs would created innovative solution for the immediate problems that would lead to sustainable social transformations (Tran \&Korflesch, 2017). Social entrepreneurship is another form of entrepreneurship which have "hybrid" form that not only concern to business activities, but it also add social value and give innovative solution to the problem (Tran \&Korflesch, 2017).

Understanding the factors that will influence social entrepreneurial intention is very important since intention is the first stage of a desired behaviour. The factors that explained in this research were positively influenced to social entreprenurial intention. Compared to entrepreneurial intention (EI) research, social entrepreneurial intention research is still left behind. The future researcher may adopt the variables proposed in El research and using larger sample size in larger scope, since this research only in a university scope. Last but not least, future researcher should explore this phenomenon more to support the social entrepreneurship development especially in Indonesia. Next, in order to promote Social Entrepreneurship, the role of government is important. Since the social entrepreneurship in Indonesia is still on the early stage, it needs the support from the party who has authority, which is government. The government of Indonesia should pay attention and give support to social entrepreneurship, since it will give more benefits to the socio-economic condition in Indonesia. The government may take a role like in making the curriculum regarding Social Entrepreneurship, increasing the intensity of social entrepreneurship promotion, giving support in terms of financial or regulation for the potential social entrepreneurs, etc. In addition the government also should attract more researcher to research more about Social Entrepreneurship issue in Indonesia, so that the government will get the best form of social entrepreneurship in Indonesia. Then, The university should take role to increase the number of students who will start social venture in the future. Social Entrepreneurship courses should be developed to get more understanding about social entrepreneurship. The courses should not only conducted theoretically, but practically. In addition, the university may take the recommendation from (Smith \& Woodworth, 2012) regarding social entrepreneurship courses implementation. It explains the 6 pedagogical techniques to teach social entrepreneurship in the class. Last but not least, hopefully most universities in Indonesia can pay more attention to social entrepreneurship since our neighboring country, Malaysia has provided social entrepreneurship course in four Malaysian universities (Ayob et al., 2013). 


\section{E. Conclusion}

1. Empathy had significant influence towards social entrepreneurial intention among the President University Faculty of Business students.

2. Self efficacy has significant influence towards social entrepreneurial intention among the President University Faculty of Business students.

3. Exposure has significant influence towards social entrepreneurial intention among the President University Faculty of Business students.

4. Empathy, self-efficacy, and exposure simultaneously have significant influence towards social entrepreneurial intention among the President University Faculty of Business students

\section{F. References}

Amanamah, R. B., Acheampong, A., \& Owusu, E. K. (2018). An Exploratory Study Of Entrepreneurial Intention Among University Students In Ghana. International Journal of Scientific \& Technology Research, 7(1), 142.

Ayob, N., Yap, C. S., Dewi, A. S., \&MdZabid, A. R. (2013). Social Entrepreneurial Intention among Business Undergraduates: An Emerging Economy Perspective Social Entrepreneurial Intention among Business Undergraduates: An Emerging Economy Perspective 1. GadjahMada International Journal of Business, 15(February 2016), 249-267. https://doi.org/10.22146/gamaijb.5470

Bandura, A. (1986). Overview of Social Cognitive Theory and of Self Efficacy.

Chipeta, E. M. (2015). Social Entrepreneurship Intentions Among University Students in Gauteng. Northwest University.

Brandon, J. (2018). New Survey Says Millennials Are the Least Entrepreneurial Generation. Retrieved from https://www.inc.com/john-brandon/new-surveysays-millennials-are-the-least-entrepreneurial-generation.html

Ebrashi, R. El. (2013). Social entrepreneurship theory and sustainable social impact. Social Responsibility Journal, 9(2), 188-209. https://doi.org/10.1108/SRJ-07-2011-0013

Enright, J. (2019). Data Show That Millennials Who Read Less Tend to Exhibit Less Empathy. Retrieved from https://civicscience.com/millennial-empathydeclining/

Esfandiar, K., Sharifi-Tehrani, M., Pratt, S., \& Altinay, L. (2017). Understanding entrepreneurial intentions: A developed integrated structural model approach. Journal of Business Research, 94(October), 172-182. https://doi.org/10.1016/j.jbusres.2017.10.045

Haque, M. R., Kabir, M. Z., Rahman, M. M., Chowdhury, S. P., \& Islam, S. (2017). Entrepreneurial Intentions: A Study on Students from Countryside University. 
Asian Economic and Financial Review, 7(10), 972-980. https://doi.org/10.18488/journal.aefr.2017.710.972.980

Hockerts, K. (2017). Determinants of Social Entrepreneurial Intentions. Entrepreneurship: Theory and Practice, 41(1), 105-130. https://doi.org/10.1111/etap.12171

Ip, C. Y., Wu, S.-C., Liu, H.-C., \& Liang, C. (2017). Revisiting the Antecedents of Social Entrepreneurial Intentions in Hong Kong. International Journal of Educational Psychology, 6(3), 301. https://doi.org/10.17583/ijep.2017.2835

Izquierdo, E. (2013). Competing Models Of Entrepreneurial Intentions : The Influence Of Entrepreneurial Self-Efficacy And Attitudes Competing Models Of Entrepreneurial Intentions: The Influence Of Entrepreneurial Self-Efficacy Entrepreneurship Education and Training, IntEnt20. Internationalizing Entrepreneurship Education and Training, IntEnt2008 Conference, 1-30. Retrieved from http://mbaadmin.americaeconomia.com/sites/mba.americaeconomia.com/files/ competing_models_of_entrepreneurial_intentions.pdf

Jamil, Z. (2014). Empathy: A motivated account. Psychological Bulletin, 140(6), 1608-1647. https://doi.org/10.1037/a0037679

Kusumasari, B. (2015). The Business Model of Social Entrepreneurship in Indonesia. Bisnis \& Birokrasi, 22(3), 156-168. Retrieved from https://search.proquest.com/docview/1845146328?accountid=13031\%0Ahttp:/ /sfx.nelliportaali.fi/nelli28b?url_ver=Z39.88-

2004\&rft_val_fmt=info:ofi/fmt:kev:mtx:journal\&genre=article\&sid=ProQ:ProQ\% 3Aabiglobal\&atitle=The+Business+Model+of+Social+Entrepreneurship

Lee, D. K., In, J., Unversity, D., Hospital, I., Lee, S., \& Hospital, S. P. (2015). Standard deviation and standard error of the mean, (September). https://doi.org/10.4097/kjae.2015.68.3.220

Luc, P. T. (2018). The Relationship between Perceived Access to Finance and Social Entrepreneurship Intentions among University Students in Vietnam. The Journal of Asian Finance, Economics and Business, 5(1), 63-72. https://doi.org/10.13106/jafeb.2018.vol5.no1.63

Marire, E., ChengedzaiMafini, \&Dhurup, M. (2017). Drivers of Entrepreneurial Intentions Amongst Generation Y Students In Zimbabwe. International Journal Of Business And Management Studies, 9(2), 18. Retrieved from http://dergipark.gov.tr/download/article-file/440213

Moses, C. L., Olokundun, M., Akinbode, M., \& Agboola, M. G. (2016). Entrepreneurship education and entrepreneurial intentions: The moderating role of passion, (January). https://doi.org/10.3923/sscience.2016.645.653

Nichols, A., Mitchell, J., \& Lindner, S. (2013). Consequences of Long-Term Unemployment. The Urban Institute. 
Rostiani, R., Paramita, W., Audita, H., Virgosita, R., Budiarto, T., \& Purnomo, B. R. (2014). Understanding Social Enterprises in Indonesia: Drivers and Challenges. Journal of Indonesian Economy and Business, 29(2), 183-191. https://doi.org/10.1124/jpet.105.094276

Sofia, I. P. (2015). Konstruksi Model Kewirausahaan Sosial Sebagai Gagasan Bagi Pembangunan Perekonomian. Jurnal Universitas Pembangunan Jaya, (June), 19.

Tran, A. T. P., \& Korflesch, H. Von. (2016). A conceptual model of social entrepreneurial intention based on the social cognitive career theory. University of Koblenz-Landau, Koblenz, Germany, 57(3-4), 113-125. https://doi.org/10.1108/APJIE-12-2016-007

Tran, A. T., \& Von Korflesch, H. (2018). Social Entrepreneurial Intention : The Case of National Economics University Students Original Research Article. Advance Research Journal of Multi-Disciplinary Discoveries I I Issue - Advance Research Journal of Multidisciplinary Discoveries. Advance Research Journal of Multi-Disciplinary Discoveries I, 232300(23), 27-34.

Urban, B. (2015). Evaluation of social enterprise outcomes and self-efficacy. International Journal of Social Economics, 42(2), 163-178. https://doi.org/10.1108/IJSE-03-2013-0071

Wang, J. H., Chang, C. C., Yao, S. N., \& Liang, C. (2016). The contribution of selfefficacy to the relationship between personality traits and entrepreneurial intention. Higher Education, 72(2), 209-224. https://doi.org/10.1007/s10734015-9946-y

Wilton, C., \& Venter, R. (2016). Identifying social entrepreneurial intent among students in South African Universities, 39. https://doi.org/10.1111/j.13652745.2011.01928.x

Ashoka. (2018). We now live in a changemaker world. Retrieved December 22, 2018, from https://www.ashoka.org/en-ID/home-0

Ashoka Foundation. (2018). Network Search. Retrieved from https://www.ashoka.org/en-ID/our-network

Depkop.go.id. (2017). Ratio Wirausaha Indonesia Naik Jadi 3,1 Persen. Retrieved November 25, 2017, from http://www.depkop.go.id/content/read/ratiowirausaha-indonesia-naik-jadi-31-persen/

Kemenko Perekonomian. (2018). Deputi Bidang Koordinasi Ekonomi Kreatif, Kewirausahaan, dan Daya Saing Koperasi dan Usaha Kecil dan Menengah. Retrieved December 22, 2018, from https://www.ekon.go.id/page/so8/

Kenya Connection. (2016). What is Social Entrepreneurship? Retrieved from https://www.kenyaconnection.org/check-out-our-summer-reading-list/ 
Lee, D. (2016). Millennials aren't big spenders or risk-takers, and that's going to reshape the economy. Retrieved from https://www.latimes.com/business/la-fithe-millennial-factor-20161010-snap-story.html

PLUS. (2018). Social Enterprise Map and Directory. Retrieved from https://usahasosial.com/community/map/

Setnas ASEAN Indonesia. (2018). Jumlah Wirausaha Indonesia Kalah Dibanding Negara Lain di ASEAN. Retrieved from http://setnasasean.id/news/read/jumlah-wirausaha-indonesia-kalah-dibanding-negara-laindi-asean

Sutha, D. A. I., \& Sankar, D. P. (2016). Entrepreneurial Intention and Social Entrepreneurship among University Students in Chennai City. International Journal of Engineering Studies, 8(1), 96. Retrieved from http://www.ripublication.com

Smith, I. H., \& Woodworth, W. P. (2012). Developing Social Entrepreneurs and Social Innovators: A Social Identity and Self-Efficacy Approach. Academy of Management Learning \& Education, 11(3), 390-407. https://doi.org/10.5465/amle.2011.0016

Utomo, H. (2015). MenumbuhkanMinatKewirausahaanSosial. --, 11(1), 159-182. https://doi.org/10.1002/sej

Worldometers. (2018). Countries in the world by population (2018). Retrieved from http://www.worldometers.info/world-population/population-by-country/

Wondra, J. D., \& Ellsworth, P. C. (2015). An Appraisal Theory of Empathy and Other Vicarious Emotional Experiences, 122(3), 411-428.

https://doi.org/http://dx.doi.org/10.1037/a0039252 